\title{
Killing the Messenger in the Nick of Time: Persistence of Breast Milk sCD14 in the Neonatal Gastrointestinal Tract
}

\author{
DAVID R. BLAIS, JOANN HARROLD, AND ILLIMAR ALTOSAAR \\ Department of Biochemistry, Microbiology and Immunology [D.R.B., I.A.], Faculty of Medicine, University of Ottawa, Ottawa, Ontario, \\ Canada, K1H 8M5; Department of Obstetrics, Gynaecology and Newborn Care [J.H.], The Ottawa Hospital, Ottawa, Ontario, \\ Canada, K1H 8 L6
}

\begin{abstract}
Human breast milk contains several proteins that supplement the newborn mucosal defense system and prevent gastrointestinal illnesses. One of these recently identified breast milk proteins is soluble CD14 (sCD14). By being an important component of the lipopolysaccharide (LPS) receptor complex, it has been suggested that breast milk sCD14 could stimulate the newborn immune system and help reduce gastrointestinal Gram-negative infections. However, to deliver its potential immune benefits to the neonate, sCD14 would have to survive the passage through the gastrointestinal tract and retain its biologic activity. We analyzed the presence of breast milk sCD14 in the neonatal digestive system and found breast milk sCD14 to be absent from the stools of breast-fed infants. In vitro digestion analysis with simulated gastric and pancreatic fluids revealed that SCD14 is likely to survive the pepsin digestion but is more prone to been nicked and digested by pancreatin. These findings suggest that the presence of intact breast milk sCD14 in the upper digestive system could promote innate immunity in this low bacteria density lumen. The low concentration of sCD14 in the LPS-rich environment of the distal gastrointestinal tract (i.e. commensal microflora) could prevent excessive inflammation. (Pediatr Res 59: 371-376, 2006)
\end{abstract}

$\mathrm{A}^{\mathrm{t}}$ $\mathrm{t}$ birth, the human immune system is not fully developed and the neonatal intestine does not yet harbor its beneficial commensal flora (1). These mucosal weaknesses make human neonates particularly vulnerable to infections and gastrointestinal illnesses. Necrotizing enterocolitis and diarrhea are such gastrointestinal disorders that can occur during the bacterial colonization of the intestine and are annually responsible for millions of infant deaths worldwide $(2,3)$.

Besides its nutritional role, breast milk is known to supplement and stimulate the infant's developing immune system with immunologically active factors, such as immunoglobulins, lysozyme, and lactoferrin, that prevent and fight gastrointestinal infections (4). However, these immunologically important molecules would have to remain intact and active throughout the gastrointestinal tract to provide immune benefits for the newborn. SIgA $(5,6)$ and lactoferrin $(7,8)$, for example, have been shown to survive the passage through the

Received June 17, 2005; accepted October 14, 2005.

Correspondence: Illimar Altosaar, Ph.D., Department of Biochemistry, Microbiology and Immunology University of Ottawa, 451 Smyth Road, Ottawa, Ontario, K1H 8M5, Canada; e-mail: altosaar@uottawa.ca

Supported by the Natural Sciences and Engineering Research Council of Canada and The Rockefeller Foundation.

DOI: $10.1203 / 01 . p d r .0000199907 .61549 .94$ infant digestive system, with observed fecal excretion rates of $160 \mathrm{mg} / \mathrm{d}$ and $14.3 \mathrm{mg} / \mathrm{d}$, respectively (6).

Recently, another immune messenger, sCD14, has been found in significant quantities $(15 \mu \mathrm{g} / \mathrm{mL})$ in breast milk $(9,10)$. CD14 plays an important role in innate immunity as the key receptor for LPS (or endotoxin), the main component of the outer membrane of Gram-negative bacteria (11). By binding to LPS, CD14 facilitates its transfer to the TLR4 and MD-2 co-receptor complex and induces the expression of various inflammatory and immunoregulatory genes, resulting in the recruitment of immune cells to the site of infection (12). In the digestive tract, the LPS co-receptor components TLR4 and MD-2 have been shown to be expressed constitutively by gastric $(13,14)$ and, to a lesser extent, by intestinal epithelial cells $(15,16)$. The presence of sCD14 has been shown to enable intestinal epithelial cells to respond to LPS in vitro $(9,10)$. Consequently, several immune functions have been proposed for breast milk sCD14 in preventing gastrointestinal Gram-negative infections and stimulating the newborn immune system $(10,17-20)$. Despite all the beneficial roles envisaged for $\mathrm{SCD} 14$, the in vivo physiologic significance of this milk-borne immune protein remains to be elucidated: does breast milk sCD14 persist throughout the neonatal digestive tract to deliver immune protection?

Therefore, the daily intake and excretion, the digestive stability, the intestinal absorption, and the proteolytic susceptibility of breast milk sCD14 were characterized in the human newborn gastrointestinal tract. To investigate the fate of breast milk sCD14 in the neonate gastrointestinal tract, feces, and urine of exclusively breast-fed neonates and formula-fed neonates were examined for sCD14 and SIgA. The proteolytic susceptibility of sCD14 was evaluated in vitro by digesting human breast milk with simulated gastric and pancreatic fluids. We propose that breast milk sCD14 is more susceptible to pancreatin proteolysis and, therefore, its absence from the newborn intestine prevents excessive inflammation during colonization by LPS-bearing microflora.

Abbreviations: LPS, lipopolysaccharide; rhCD14, recombinant human CD14; sCD14, soluble CD14; SIgA, secretory IgA; TLR4, toll-like receptor 4 


\section{METHODS}

Subjects. The study was conducted according to the principles expressed in the Declaration of Helsinki and was approved by the Ottawa Hospital Research Ethics Board. Two groups of neonates $(n=28)$, born at the Ottawa Hospital, were enrolled within $1 \mathrm{~d}$ after birth when the purpose of the research and the experimental procedure were explained to the parents and their informed consent obtained. The first group was composed of 15 newborns ( 7 girls and 8 boys) who were exclusively breast-fed. The second group consisted of 13 newborns (6 girls and 7 boys) who were exclusively formula-fed with their preferred milk formulas (Enfalac, Similac, or Nestlé Good Start). All infants were healthy and born at term (38-42 wk), with a birth weight ranging between 3.1 and $4.1 \mathrm{~kg}$.

Sample collection. Three 24-h collections were performed on each newborn in their own home at $1 \mathrm{wk}(6-9 \mathrm{~d}), 2 \mathrm{wk}(12-16 \mathrm{~d})$, and $4 \mathrm{wk}(26-32$ d) of age. For each collection, the participants were asked to collect for a period of $24 \mathrm{~h}$ the infant feces and urine using Kushies diaper liners (D.D.F. Inc., Stoney Creek, ON, Canada). Milk intake of each infant was measured for $24 \mathrm{~h}$ using the difference in body weight before and after each nursing. The weight of milk was converted to volume using its specific gravity of 1.031 $\mathrm{g} / \mathrm{mL}$ (21). On each collection day, breast-feeding mothers hand-expressed a small milk sample, whereas formula-feeding mothers provided a small sample of commercial formula milk. All samples were immediately frozen $\left(-20^{\circ} \mathrm{C}\right)$ until analysis $(1-2 \mathrm{~d})$.

Sample preparation. Diaper liners containing urine were gently squeezed and the extracted urine was frozen until analysis. Diaper liners containing fecal material were weighed and the feces were scraped from the diaper liners. The feces were homogenized in PBS (1:2) containing a protease inhibitor (Sigma Chemical Co.-Aldrich, St. Louis, MO) and incubated on ice for 30 $\mathrm{min}$. The extract was centrifuged at $10,000 \times \mathrm{g}$ for $20 \mathrm{~min}$ at $4^{\circ} \mathrm{C}$ to sediment any insoluble material.

Reagents. The quantification of sCD14 and SIgA proteins was performed using a human sCD14 ELISA (HyCult Biotechnology, Uden, The Netherlands) and a human IgA ELISA (Bethyl Laboratories Inc., Montgomery, TX). Commercial recombinant human CD14 (rhCD14) (R \& D Systems, Minneapolis, MN) and purified breast milk human SIgA (Serotec Ltd., Oxford, UK) served as controls in the in vitro digestion analysis. Immunodetection was performed using the biotinylated polyclonal anti-human CD14 (R \& D Systems) and the biotinylated $\alpha$-chain-specific anti-human IgA (Caltag Laboratories, Burlingame, CA). Human AB serum (Sigma Chemical Co.-Aldrich) was used as a loading control.

In vitro digestion of rhCD14, purified SIgA, and breast milk. The procedure was slightly modified from Rudloff and Lonnerdal (22). For pepsin digestion, the $\mathrm{pH}$ of control proteins sCD14 $(10 \mathrm{ng} / \mathrm{mL})$, SIgA $(10 \mathrm{ng} / \mathrm{mL})$, and breast milk were adjusted to 4.5 with $1 \mathrm{M} \mathrm{HCl}$. Each sample was aliquoted and pepsin (porcine gastric mucosa, 800-2500 U/mg, Sigma Chemical Co.) was added to the desired concentration. The samples were incubated at $37^{\circ} \mathrm{C}$ for $30 \mathrm{~min}$ with occasional shaking.

Pancreatin digestion was performed by adjusting the $\mathrm{pH}$ of the samples to 7.0 with $1 \mathrm{M} \mathrm{HCl}$ or $1 \mathrm{M} \mathrm{NaHCO}_{3}$. Each sample was aliquoted and pancreatin (porcine pancreas, $4 \times$ USP, Sigma Chemical Co.) was added to the desired concentration. The samples were digested at $37^{\circ} \mathrm{C}$ for $1 \mathrm{~h}$.

Sequential digestions with simulated gastric and pancreatic fluids were performed by adjusting the $\mathrm{pH}$ of the samples to 4.5 with $1 \mathrm{M} \mathrm{HCl}$ and pepsin was added $(1 \mathrm{mg} / \mathrm{mL})$. The samples were incubated at $37^{\circ} \mathrm{C}$ for $30-60 \mathrm{~min}$. After the pepsin digestion, the $\mathrm{pH}$ of each sample was increased gradually (10 min) to 7.0 with $1 \mathrm{M} \mathrm{NaHCO}_{3}$ and pancreatin was added $(1 \mathrm{mg} / \mathrm{mL})$. The samples were incubated at $37^{\circ} \mathrm{C}$ for $60-120 \mathrm{~min}$ with occasional shaking.
Immunoblotting. Samples were resolved by reducing SDS-PAGE electrophoresis (11\% resolving gel) and transferred onto nitrocellulose. The sCD14 and SIgA proteins were probed with the anti-human CD14 $(0.05 \mu \mathrm{g} / \mathrm{mL})$ or with the anti-human $\operatorname{IgA}(0.07 \mu \mathrm{g} / \mathrm{mL})$, followed with the anti-biotin HRPconjugated antibody $(1: 1,000)$ (Cell Signaling Technology, Beverly, MA). The antigens were detected with the ECL Detection Reagents (Amersham Biosciences, Piscataway, NJ).

Statistical analysis. Individual experiments were performed in triplicate. Values are represented as mean $\pm \mathrm{SD}$. The statistical significance of differences was evaluated using ANOVA, where $p$ values $<0.05$ were considered statistically significant.

\section{RESULTS}

Breast milk sCD14 is not excreted by the newborn. To analyze the stability of breast milk sCD14 in the newborn digestive system, the input (breast milk) and the output (feces and urine) levels of sCD14 were measured by ELISA and compared with SIgA, a breast milk antibody known for its gastrointestinal persistence $(5,6)$. To ensure that the output levels of sCD14 and SIgA did not originate from in vivo gastrointestinal synthesis, formula-fed neonates were recruited as a control group, because sCD14 and SIgA were not detectable in commercial milk formulas (Tables 1 and 2). The lack of detection of sCD14 and SIgA in milk formulas could be attributed to the absence of these proteins in the commercial preparations or to the inability of the ELISA and antibodies to detect the bovine sCD14 and SIgA proteins. In the study group, both sCD14 and SIgA could be observed in all breast milk samples, with SIgA levels being on average 30 times higher than sCD14 (Tables 1 and 2). The output fecal and urinary levels of sCD14 were similar between breast-fed and formula-fed neonates (Table 1). However, SIgA was present in higher concentration, 1000- and 10-fold respectively, in feces and urine samples from breast-fed neonates when compared with formula-fed newborns (Table 2). To rule out any presence of aggregated or adsorbed sCD14 proteins in the stool matrix that would be nonextractable with PBS, harsher extraction techniques with detergents were performed on stool samples. These stronger extraction procedures generated similar fecal sCD14 levels to those of the PBS extraction, with no significant difference observed between the two techniques (unpublished observations). Furthermore, stool homogenate spiked with rhCD14 $(8 \mathrm{ng} / \mathrm{mL})$ revealed that the constituents of the stool extract did not impede the reactivity of the sCD14 antigens with the ELISA kit, since a rhCD14 concentration of

Table 1. CD14 concentration in breast milk, in milk formula, and in the urine and feces of breast-fed and formula-fed infants

\begin{tabular}{|c|c|c|c|c|c|c|}
\hline \multirow[b]{2}{*}{ Samples } & \multicolumn{3}{|c|}{$\begin{array}{l}\text { Breast-fed neonates } \\
\qquad(\mathrm{n}=15)\end{array}$} & \multicolumn{3}{|c|}{$\begin{array}{l}\text { Formula-fed neonates } \\
\qquad(\mathrm{n}=13)\end{array}$} \\
\hline & $\begin{array}{l}\text { Breast milk } \\
(\mathrm{ng} / \mathrm{mL})^{*}\end{array}$ & $\begin{array}{c}\text { Urine } \\
(\mathrm{ng} / \mathrm{mL})^{*}\end{array}$ & $\begin{array}{c}\text { Feces } \\
\left(\mathrm{ng} / \mathrm{g}_{\mathrm{fw}}\right)^{*}\end{array}$ & $\begin{array}{l}\text { Milk formula } \\
(\mathrm{ng} / \mathrm{mL})^{*}\end{array}$ & $\begin{array}{c}\text { Urine } \\
(\mathrm{ng} / \mathrm{mL})^{*}\end{array}$ & $\begin{array}{c}\text { Feces } \\
\left(\mathrm{ng} / \mathrm{g}_{\mathrm{fw}}\right)^{*}\end{array}$ \\
\hline \multicolumn{7}{|l|}{ Age (wk) } \\
\hline 1 & $29,500 \pm 15,400 \dagger$ & $47.8 \pm 86.3$ & $4.1 \pm 9.6$ & $0.4 \pm 0.7$ & $37.6 \pm 69.8$ & $11.7 \pm 27.3$ \\
\hline 2 & $25,100 \pm 11,900 \dagger$ & $1.6 \pm 3.4$ & $8.0 \pm 15.0$ & $0.6 \pm 1.8$ & $10.2 \pm 10.3$ & $3.8 \pm 4.6$ \\
\hline
\end{tabular}

* The quantification of CD14 in the collected samples was performed by ELISA using a commercially available kit.

Statistically significant differences between samples from breast-fed and formula-fed newborns were determined using ANOVA, with probabilities $\dagger p<$ 0.0001 . 
Table 2. IgA concentration in breast milk, in milk formula, and in the urine and feces of breast-fed and formula-fed infants

\begin{tabular}{|c|c|c|c|c|c|c|}
\hline \multirow[b]{2}{*}{ Samples } & \multicolumn{3}{|c|}{$\begin{array}{l}\text { Breast-fed neonates } \\
\quad(\mathrm{n}=15)\end{array}$} & \multicolumn{3}{|c|}{$\begin{array}{l}\text { Formula-fed neonates } \\
\qquad(\mathrm{n}=13)\end{array}$} \\
\hline & $\begin{array}{c}\text { Breast milk } \\
(\mu \mathrm{g} / \mathrm{mL})^{*}\end{array}$ & $\begin{array}{c}\text { Urine } \\
(\mu \mathrm{g} / \mathrm{mL})^{*}\end{array}$ & $\begin{array}{c}\text { Feces } \\
\left(\mu \mathrm{g} / \mathrm{g}_{\mathrm{fw}}\right)^{*}\end{array}$ & $\begin{array}{l}\text { Milk formula } \\
(\mu \mathrm{g} / \mathrm{mL})^{*}\end{array}$ & $\begin{array}{c}\text { Urine } \\
(\mu \mathrm{g} / \mathrm{mL})^{*}\end{array}$ & $\begin{array}{c}\text { Feces } \\
\left(\mu \mathrm{g} / \mathrm{g}_{\mathrm{fw}}\right)^{*}\end{array}$ \\
\hline \multicolumn{7}{|l|}{ Age (wk) } \\
\hline 1 & $991 \pm 682 \dagger$ & $3.9 \pm 9.6$ & $1,559 \pm 999 \dagger$ & $0 \pm 0$ & $0 \pm 0$ & $2.1 \pm 1.6$ \\
\hline 2 & $831 \pm 624 \dagger$ & $2.0 \pm 2.2 \ddagger$ & $1,569 \pm 988 \dagger$ & $0 \pm 0$ & $0.1 \pm 0.1$ & $14.7 \pm 27.3$ \\
\hline
\end{tabular}

* The quantification of IgA in the collected samples was performed by ELISA using a commercially available kit.

Statistically significant differences between samples from breast-fed and formula-fed newborns were determined using ANOVA, with probabilities $\dagger p<$ $0.0005, \ddagger p<0.01$.

$8.7 \mathrm{ng} / \mathrm{mL}$ was detected. The daily intake and excretion of sCD14 and SIgA per unit body weight showed that breast-fed infants excreted considerably higher quantities of SIgA (1800 $\pm 1700 \mu \mathrm{g} / \mathrm{kg} / \mathrm{d})$ when compared with formula-fed infants (15 $\pm 27 \mu \mathrm{g} / \mathrm{kg} / \mathrm{d}$ ) (Fig. 1). Despite the significant difference in sCD14 intake between breast-fed (3300 $\pm 2300 \mu \mathrm{g} / \mathrm{kg} / \mathrm{d})$ and formula-fed $(0.05 \pm 0.15 \mu \mathrm{g} / \mathrm{kg} / \mathrm{d})$ infants, the daily excretory levels of sCD14 were similar $(0.005 \pm 0.009 \mu \mathrm{g} / \mathrm{kg} / \mathrm{d}$ for breast-fed and $0.007 \pm 0.014 \mu \mathrm{g} / \mathrm{kg} / \mathrm{d}$ for formula-fed) between the two groups, albeit the fecal concentrations were minute (Fig. 1).

The lack of significant CD14 excretory levels could also be attributed to the inability of the ELISA antibodies to detect CD14 digested fragments. Therefore, immunoblotting was performed using polyclonal anti-CD14 antibodies. Two polypeptides of molecular mass of 48 and $52 \mathrm{kD}$ were detected with the anti-CD14 antibody in breast milk and serum, whereas only a $52 \mathrm{kD}$ polypeptide was observed in the urine of breast-fed and formula-fed infants, corresponding to the size of sCD14 detected in the adult urine sample (Fig. 2A). Immunoblot analysis with the anti-IgA antibody also revealed the $60 \mathrm{kD}$ heavy chain polypeptide of SIgA in breast milk as well as in the stool and urine of breast-fed newborns, which corresponded to the same apparent molecular mass of the heavy chain of serum IgA (Fig. 2B). Smaller polypeptides, likely representing digested fragments of SIgA, were also detected by the anti-IgA antibody in fecal samples of breastfed infants (Fig. 2B).

A
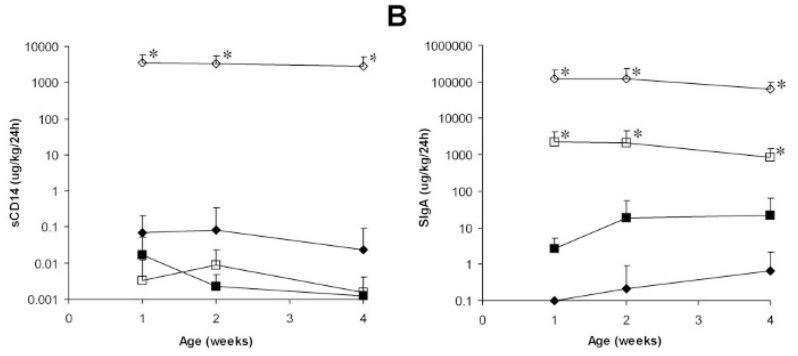

Figure 1. Daily intake and fecal excretion of $\operatorname{sCD} 14(A)$ and $\operatorname{SIgA}(B)$ in exclusively breast-fed $(n=15)$ or formula-fed $(n=13)$ infants. The quantification of SCD14 and SIgA in milk and newborn stool homogenate was performed by ELISA. Breast-fed intake $(\diamond)$, breast-fed excretion $(\square)$, formula-fed intake ( ), formula-fed excretion (ם). Statistically significant differences between samples from breast-fed and formula-fed newborns were determined using ANOVA $(* p<0.0005)$.

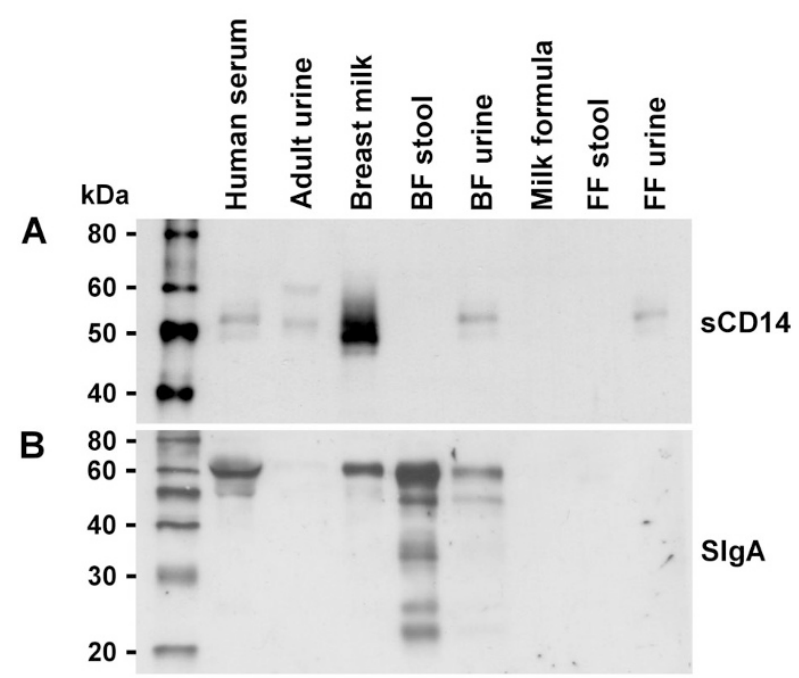

Figure 2. Immunodetection of human $\operatorname{sCD} 14(A)$ and $\operatorname{SIgA}(B)$ in various samples from breast-fed and formula-fed infants. Breast-fed $(B F)$ and formula-fed $(F F)$ infant samples along with serum and adult urine controls were subjected to Western blotting under reducing conditions with the biotinylated anti-CD14 polyclonal antibody $(A)$ or the biotinylated anti-IgA polyclonal antibody $(B)$, followed by the anti-biotin HRP-linked antibody. The immunoblots are representative of three different mother-neonate groups.

Breast milk sCD14 is more susceptible to pancreatin digestion than pepsin digestion. To investigate the susceptibility of SCD14 to digestion in comparison to SIgA, both proteins were subjected to in vitro proteolysis with porcine pepsin and pancreatin enzymes. Both sCD14 and SIgA, in their recombinant form and naturally present in breast milk, showed a similar resistance to pepsin digestion (Fig. 3). Breast milk samples continued to show the intact molecular weight of both proteins after the $10 \mathrm{mg} / \mathrm{mL}$ pepsin digestion (Fig. 3). For the pancreatin digestions, control rhCD14 and SIgA also had a similar and high susceptibility to the enzyme, with no protein detectable after the $0.1 \mathrm{mg} / \mathrm{mL}$ pancreatin digestion (Fig. 4). In breast milk, however, SIgA showed more resistance to porcine pancreatin, where no sCD14 survived the $10 \mathrm{mg} / \mathrm{mL}$ digestion (Fig. 4, lane 10). During the sequential pepsin and pancreatin digestions, both control proteins were proteolyzed, whereas in breast milk, SIgA showed a stronger resistance to proteolysis when compared with sCD14 (Fig. 5). Approximately half of breast milk sCD14 proteins were degraded in the shortest digestion period and no protein remained visible 


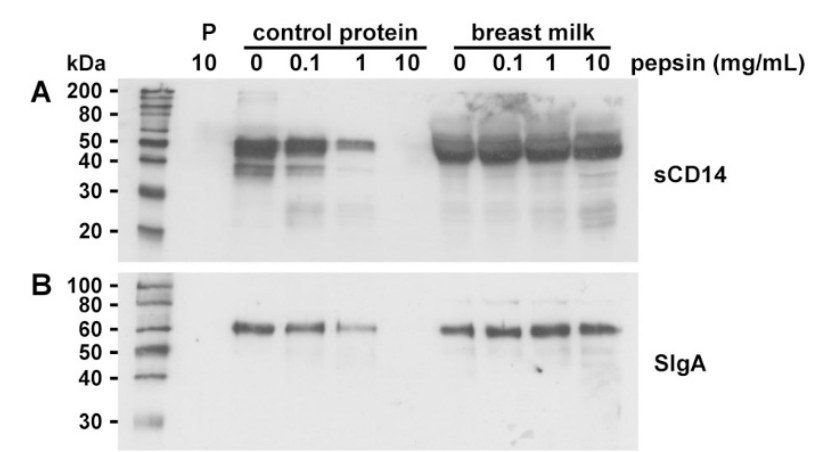

Figure 3. Western analysis of pepsin digested human breast milk, control rhCD14 $(A)$, and SIgA $(B)$. The control proteins, rhCD14 and SIgA (10 $\mathrm{ng} / \mathrm{mL}$ ), and breast milk were digested in vitro with the indicated concentrations of pepsin for $30 \mathrm{~min}$ at $37^{\circ} \mathrm{C}, \mathrm{pH} 4.5$, and subjected to Western blotting under reducing conditions with the biotinylated anti-CD14 polyclonal antibody $(A)$ or the biotinylated anti-IgA polyclonal antibody $(B)$, followed by the anti-biotin HRP-linked antibody. Lane P represents porcine pepsin $(10 \mathrm{mg} /$ $\mathrm{mL}$ ) as a loading control. The immunoblots are representative of three independent digestions performed on different breast milk samples.

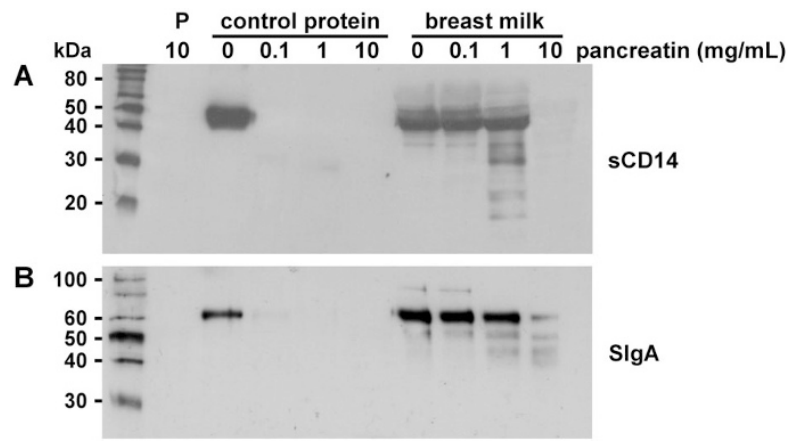

Figure 4. Western analysis of pancreatin digested human breast milk, control rhCD14 $(A)$ and $\operatorname{SIgA}(B)$. The control proteins, rhCD14 and SIgA (10 $\mathrm{ng} / \mathrm{mL}$ ), and breast milk were digested in vitro with the indicated concentrations of pancreatin for $60 \mathrm{~min}$ at $37^{\circ} \mathrm{C}, \mathrm{pH} \mathrm{7.0}$. and subjected to Western blotting under reducing conditions with the biotinylated anti-CD14 polyclonal antibody $(A)$ or the biotinylated anti-IgA polyclonal antibody $(B)$, followed by the anti-biotin HRP-linked antibody. Lane P represents porcine pancreatin (10 $\mathrm{mg} / \mathrm{mL}$ ) as a loading control. The immunoblots are representative of three independent digestions performed on different breast milk samples.

after the longest digestion period (Fig. 5). For breast milk SIgA, the sequential digestions were less effective, where approximately one quarter of the original amount of the protein was still remaining after the longest digestion (Fig. 5). The multiple smaller bands detected on the blots likely represent digested products of sCD14 or SIgA, which were absent in nondigested samples (Figs. 3-5). In general, the sCD14 and SIgA proteins in breast milk showed a higher resistance to pepsin and pancreatin digestions than the control proteins (Figs. 3-5).

\section{DISCUSSION}

The results presented in this study suggest that most breast milk sCD14 proteins are unlikely to persist in the newborn gastrointestinal tract. This finding is supported by the trace excretory levels $(5.4 \pm 11.0 \mathrm{ng} / \mathrm{g})$ of sCD14 observed in feces of both exclusively breast-fed (intake of $25.6 \pm 13.8 \mu \mathrm{g} / \mathrm{mL}$ of sCD14) and formula-fed neonates (virtually no intake of sCD14). These observations were constant at three time points

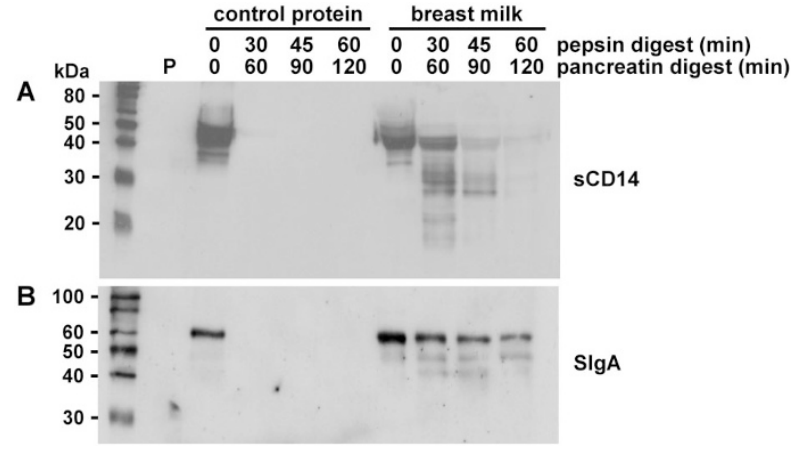

Figure 5. Western analysis of sequential digestion of human breast milk, control rhCD14 $(A)$ and SIgA $(B)$ with simulated gastric and pancreatic fluids. The control proteins, rhCD14 and SIgA $(10 \mathrm{ng} / \mathrm{mL})$, and breast milk were digested in vitro at various incubation times with pepsin $(1 \mathrm{mg} / \mathrm{mL})$ at $37^{\circ} \mathrm{C}$, $\mathrm{pH} 4.5$ followed by a pancreatin digestion $(1 \mathrm{mg} / \mathrm{mL})$ at $37^{\circ} \mathrm{C}, \mathrm{pH} 7.0$, and subjected to Western blotting under reducing conditions with the biotinylated anti-CD14 polyclonal antibody $(A)$ or the biotinylated anti-IgA polyclonal antibody $(B)$, followed by the anti-biotin HRP-linked antibody. Lane $\mathrm{P}$ represents porcine pepsin $(1 \mathrm{mg} / \mathrm{mL})$ and pancreatin $(1 \mathrm{mg} / \mathrm{mL})$ as a loading control. The immunoblots are representative of three independent digestions performed on breast milk samples.

during the first month of life of the human newborn, when the gastrointestinal tract is maturing. Furthermore, the trace levels of fecal sCD14 measured in both breast-fed and formula-fed infants could result from endogenous intestinal synthesis of sCD14 (23) or could be related to analytical variations at the lower limit of detection of the ELISA kit. However, the minute concentration of fecal SCD14 measured from formulafed neonates suggests that the endogenous intestinal secretion of sCD14 is very limited or its intestinal fate restricts its detection in stools.

By contrast, breast milk SIgA was detected in high quantity in the stools of breast-fed newborns $(1500 \mu \mathrm{g} / \mathrm{g})$, confirming its persistence in the gastrointestinal tract $(5,6)$. The gastrointestinal persistence of SIgA is largely attributed to its high degree of glycosylation and to the presence of the bound secretory component, rendering this dimeric antibody inherently resistant to luminal proteolysis (24). This fecal SIgA difference observed between breast-fed and formula-fed neonates validates the methodology used to measure the passage of intact breast milk proteins in the newborn gastrointestinal tract.

The lack of detection of breast milk sCD14 in stools of breast-fed infants suggests two possible gastrointestinal fates of sCD14: i) efficient transport, in an intact and active form, through the intestinal mucosa to contribute to the serum pool of sCD14, and/or ii) digestion and degradation by the gastrointestinal enzymes to restrict its biologic activity along the newborn intestinal tract.

The first potential fate of breast milk sCD14 was investigated by analyzing the levels of sCD14 in the urine of breast-fed and formula-fed neonates. The quantification of urinary proteins is a suitable technique to estimate the serum concentration of specific proteins in the newborn without having to resort to invasive procedures $(25,26)$. In both breastfed and formula-fed groups, urinary sCD14 detected by immunoblot had a similar electrophoretic mobility to sCD14 
found in human adult urine (27). However, the similar urinary sCD14 levels between breast-fed and formula-fed newborns measured by ELISA do not support the notion of its absorption through the intestinal mucosa and its subsequent renal excretion. Even within the first week of age, when the small intestine is known to have an enhanced permeability to macromolecules coming in contact with its mucosa (28), no differences in urinary sCD14 levels were observed. In contrast, breast milk SIgA has been shown to be absorbed into the serum by the newborn intestinal mucosa within the first week of life (28), which was observed with higher urinary SIgA levels (25). These results suggest that SCD14 detected in urine samples is endogenous in origin and is unlikely to originate from the intestinal absorption of breast milk sCD14.

Secondly, the digestibility of breast milk sCD14 was investigated in vitro with simulated gastric juices and revealed that the protein is resistant to pepsin digestion. This gastric resistance can be attributed to the low secretion of hydrochloric acid in the neonatal stomach, resulting in a $\mathrm{pH}$ of 3.5-5, far higher than the optimal $\mathrm{pH}$ conditions of pepsin (29). In this study, the conditions of the in vitro model of gastric digestion ( $\mathrm{pH} 4.5$ for 30-60 min) were designed to reflect the neonatal gastric environment (22). The relative abundance of SCD14 in breast milk $(25.6 \pm 13.8 \mu \mathrm{g} / \mathrm{mL})$, when compared with its serum concentration ( $3 \mu \mathrm{g} / \mathrm{mL})(9)$, and its relative resistance to pepsin digestion, may allow significant amounts of the intact protein to reach the duodenum. Furthermore, the enhanced proteolytic resistance observed for both breast milk sCD14 and SIgA, in comparison to their purified forms, may be attributed to the breast milk abundance of alternate substrates for the digestive enzymes and to breast milk protease inhibitors (30). The first N-terminal half of sCD14 has been shown to contain all the active domains to trigger biologic responses against LPS (31). As a result, partially digested forms of sCD14, in addition to its undigested form, could offer immune protection to the upper digestive tract (oral cavity, esophagus, and stomach), where low bacterial density is found (32). Breast milk sCD14 could also modulate the LPS response by interacting with other breast milk immune proteins, such as lactoferrin (33) and TLR2 (34), and prevent excessive immune reactions and inflammation. Breast milk sCD14 could reduce the luminal bioavailability of free LPS monomers by transferring them to lactoferrin (33) and prevent the interaction of endotoxin with intestinal epithelial cells. Another CD14 co-receptor, soluble TLR2, recently found in breast milk, could also interact with sCD14 to avoid excessive local inflammation against Gram-positive bacteria and mycobacteria present in the neonatal intestinal tract (34).

The increased proteolytic susceptibility of breast milk sCD14 to pancreatic fluids under representative in vivo neonatal duodenal conditions ( $\mathrm{pH} 7.0$ for 1-2 h), when compared with breast milk SIgA, suggests that only a fraction of SCD14 ingested by the neonate may persist the duodenal passage. These results could explain the trace amounts of sCD14 observed in the stools of breast-fed neonates. Furthermore, breast milk sCD14 proteins could be subjected to additional hydrolysis during their jejunum, ileum, and colon transit by proteolytic enzymes of bacterial and intestinal origin (35). By binding to LPS, sCD14 cannot discriminate between harmful pathogenic and beneficial commensal Gram-negative bacteria. Therefore, the absence or trace amounts of sCD14 in the small intestine and colon, in addition to the low intestinal expression of TLR4, could be solutions in preventing uncontrolled and detrimental immune responses in this heavily colonized environment (32). In contrast, the gastrointestinal persistence of breast milk SIgA is considered beneficial to the newborn due to its specificity in targeting pathogens to which the nursing mother has been exposed and consequently preventing their penetration through the neonatal intestinal mucosa $(4,36)$. These results suggest that breast milk sCD14 has a very limited presence in the distal gastrointestinal tract to avoid excessive mucosal inflammation in this densely colonized environment. It is also possible that the immune protective effect of breast milk sCD14 is limited to the nursing mother, as bovine sCD14 has been shown to reduce the severity of mastitis by increasing the recruitment of immune cells to the site of infection (37).

In summary, our findings suggest that breast milk sCD14 is more susceptible to pancreatin digestion and is not excreted in feces. This nonubiquitous gastrointestinal presence may allow sCD14 to contribute to immune protection against Gramnegative pathogens in the upper digestive tract while reducing its inflammatory activity in the LPS-rich environment of the distal bowel. Further studies exploring the gastrointestinal passage and the distribution of breast milk sCD14 by collecting gastric and duodenal secretions from human newborns and from suckling animal models fed human breast milk will enhance our understanding of the molecular interactions between breast milk sCD14, the newborn gastrointestinal lumen, and the gut microflora. These studies may lead to the development of efficient treatments to enhance the newborn innate immune defences and prevent Gram-negative complications, such as necrotizing enterocolitis and diarrhea.

Acknowledgments. The authors thank all the families who volunteered in this project. We also thank M. McNulty, F.W. Scott, and K. Vidal for their helpful comments on the manuscript.

\section{REFERENCES}

1. Adkins B, Leclerc C, Marshall-Clarke S 2004 Neonatal adaptive immunity comes of age. Nat Rev Immunol 4:553-564

2. Nanthakumar NN, Fusunyan RD, Sanderson I, Walker WA 2000 Inflammation in the developing human intestine: a possible pathophysiologic contribution to necrotizing enterocolitis. Proc Natl Acad Sci U S A 97:6043-6048

3. Wenneras C, Erling V 2004 Prevalence of enterotoxigenic Escherichia coliassociated diarrhoea and carrier state in the developing world. J Health Popul Nutr 22:370-382

4. Lonnerdal B 2004 Human milk proteins: key components for the biological activity of human milk. Adv Exp Med Biol 554:11-25

5. Haneberg B 1974 Immunoglobulins in feces from infants fed human or bovine milk. Scand J Immunol 3:191-197

6. Prentice A, Ewing G, Roberts SB, Lucas A, MacCarthy A, Jarjou LM, Whitehead RG 1987 The nutritional role of breast-milk IgA and lactoferrin. Acta Paediatr Scand 76:592-598

7. Davidson LA, Lonnerdal B 1987 Persistence of human milk proteins in the breastfed infant. Acta Paediatr Scand 76:733-740

8. Goldman AS, Garza C, Schanler RJ, Goldblum RM 1990 Molecular forms of lactoferrin in stool and urine from infants fed human milk. Pediatr Res 27:252-255

9. Labeta MO, Vidal K, Nores JE, Arias M, Vita N, Morgan BP, Guillemot JC, Loyaux D, Ferrara P, Schmid D, Affolter M, Borysiewicz LK, Donnet-Hughes A, Schiffrin EJ 2000 Innate recognition of bacteria in human milk is mediated by a milk-derived 
highly expressed pattern recognition receptor, soluble CD14. J Exp Med 191:18071812

10. Vidal K, Labeta MO, Schiffrin EJ, Donnet-Hughes A 2001 Soluble CD14 in human breast milk and its role in innate immune responses. Acta Odontol Scand 59:330 334

11. Wright SD, Ramos RA, Tobias PS, Ulevitch RJ, Mathison JC 1990 CD14, a receptor for complexes of lipopolysaccharide (LPS) and LPS binding protein. Science 249:1431-1433

12. Chow JC, Young DW, Golenbock DT, Christ WJ, Gusovsky F 1999 Toll-like receptor-4 mediates lipopolysaccharide-induced signal transduction. J Biol Chem 274:10689-10692

13. Ishihara S, Rumi MA, Kadowaki Y, Ortega-Cava CF, Yuki T, Yoshino N, Miyaoka Y, Kazumori H, Ishimura N, Amano Y, Kinoshita Y 2004 Essential role of MD-2 in TLR4-dependent signaling during Helicobacter pylori-associated gastritis. J Immunol 173:1406-1416

14. Schmausser B, Andrulis M, Endrich S, Lee SK, Josenhans C, Muller-Hermelink HK, Eck M 2004 Expression and subcellular distribution of toll-like receptors TLR4, TLR5 and TLR9 on the gastric epithelium in Helicobacter pylori infection. Clin Exp Immunol 136:521-526

15. Bocker U, Yezerskyy O, Feick P, Manigold T, Panja A, Kalina U, Herweck F, Rossol S, Singer MV 2003 Responsiveness of intestinal epithelial cell lines to lipopolysaccharide is correlated with Toll-like receptor 4 but not Toll-like receptor 2 or CD14 expression. Int J Colorectal Dis 18:25-32

16. Ortega-Cava CF, Ishihara S, Rumi MA, Kawashima K, Ishimura N, Kazumori H, Udagawa J, Kadowaki Y, Kinoshita Y 2003 Strategic compartmentalization of Toll-like receptor 4 in the mouse gut. J Immunol 170:3977-3985

17. Vidal K, Donnet-Hughes A, Granato D 2002 Lipoteichoic acids from Lactobacillus johnsonii strain La1 and Lactobacillus acidophilus strain La10 antagonize the responsiveness of human intestinal epithelial HT29 cells to lipopolysaccharide and gram-negative bacteria. Infect Immun 70:2057-2064

18. Filipp D, Alizadeh-Khiavi K, Richardson C, Palma A, Paredes N, Takeuchi O, Akira S, Julius M 2001 Soluble CD14 enriched in colostrum and milk induces B cell growth and differentiation. Proc Natl Acad Sci U S A 98:603-608

19. Arias MA, Rey Nores JE, Vita N, Stelter F, Borysiewicz LK, Ferrara P, Labeta MO 2000 Human B cell function is regulated by interaction with soluble CD14: opposite effects on IgG1 and IgE production. J Immunol 164:3480-3486

20. Jones CA, Holloway JA, Popplewell EJ, Diaper ND, Holloway JW, Vance GH, Warner JA, Warner JO 2002 Reduced soluble CD14 levels in amniotic fluid and breast milk are associated with the subsequent development of atopy, eczema, or both. J Allergy Clin Immunol 109:858-866

21. Pao EM, Himes JM, Roche AF 1980 Milk intakes and feeding patterns of breast-fed infants. J Am Diet Assoc 77:540-545

22. Rudloff S, Lonnerdal B 1992 Solubility and digestibility of milk proteins in infant formulas exposed to different heat treatments. J Pediatr Gastroenterol Nutr 15:25-33
23. Funda DP, Tuckova L, Farre MA, Iwase T, Moro I, Tlaskalova-Hogenova H 2001 CD14 is expressed and released as soluble CD14 by human intestinal epithelial cells in vitro: lipopolysaccharide activation of epithelial cells revisited. Infect Immun 69:3772-3781

24. Lindh E 1975 Increased resistance of immunoglobulin A dimers to proteolytic degradation after binding of secretory component. J Immunol 114:284-286

25. Goldblum RM, Schanler RJ, Garza C, Goldman AS 1989 Human milk feeding enhances the urinary excretion of immunologic factors in low birth weight infants. Pediatr Res 25:184-188

26. Hutchens TW, Henry JF, Yip TT 1991 Structurally intact (78-kDa) forms of maternal lactoferrin purified from urine of preterm infants fed human milk: identification of a trypsin-like proteolytic cleavage event in vivo that does not result in fragment dissociation. Proc Natl Acad Sci U S A 88:2994-2998

27. Bussolati B, David S, Cambi V, Tobias PS, Camussi G 2002 Urinary soluble CD14 mediates human proximal tubular epithelial cell injury induced by LPS. Int J Mol Med 10:441-449

28. Vukavic T 1983 Intestinal absorption of IgA in the newborn. J Pediatr Gastroenterol Nutr 2:248-251

29. Piper DW, Fenton BH 1965 pH stability and activity curves of pepsin with special reference to their clinical importance. Gut 6:506-508

30. Lindberg T, Ohlsson K, Westrom B 1982 Protease inhibitors and their relation to protease activity in human milk. Pediatr Res 16:479-483

31. Juan TS, Kelley MJ, Johnson DA, Busse LA, Hailman E, Wright SD, Lichenstein HS 1995 Soluble CD14 truncated at amino acid 152 binds lipopolysaccharide (LPS) and enables cellular response to LPS. J Biol Chem 270:1382-1387

32. Macpherson AJ, Harris NL 2004 Interactions between commensal intestinal bacteria and the immune system. Nat Rev Immunol 4:478-485

33. Baveye S, Elass E, Fernig DG, Blanquart C, Mazurier J, Legrand D 2000 Human lactoferrin interacts with soluble CD14 and inhibits expression of endothelial adhesion molecules, E-selectin and ICAM-1, induced by the CD14-lipopolysaccharide complex. Infect Immun 68:6519-6525

34. LeBouder E, Rey-Nores JE, Rushmere NK, Grigorov M, Lawn SD, Affolter M, Griffin GE, Ferrara P, Schiffrin EJ, Morgan BP, Labeta MO 2003 Soluble forms of Toll-like receptor (TLR)2 capable of modulating TLR2 signaling are present in human plasma and breast milk. J Immunol 171:6680-6689

35. Britton JR, Koldovsky O 1989 Development of luminal protein digestion: implications for biologically active dietary polypeptides. J Pediatr Gastroenterol Nutr 9:144-162

36. Brandtzaeg P 2003 Mucosal immunity: integration between mother and the breastfed infant. Vaccine 21:3382-3388

37. Lee JW, Paape MJ, Elsasser TH, Zhao X 2003 Recombinant soluble CD14 reduce severity of intramammary infection by Escherichia coli. Infect Immun 71:40344039 